\title{
Instructors' Readiness to Teach Online: A Review of TPACK Standards in Online Professional Development Programmes in Higher Education
}

\author{
Amjaad Mujallid \\ King Abdul Aziz University, Jeddah, Saudi Arabia \\ https://orcid.org/0000-0002-3844-2141
}

\begin{abstract}
Online learning has been developed in higher education offering a flexible environment for learners. Faculty knowledge is among the most important domains required to be updated in order to ensure a successful integration of instructional technology and online learning in higher education. This update can be performed by providing faculty training on how to use technology. However, this should be integrated with pedagogical knowledge, which is represented in the Technological Pedagogical and Content Knowledge framework (TPACK). This paper reviewed the literature to find how higher education institutions support online instructors with professional development programmes and, moreover, to discover how these programmes are shaped by the TPACK framework. The paper also summarises the effective online teaching practices based on the TPACK framework presented in the literature. Teaching online is a challenge and does not mean having to move traditional instructions and activities into the online platform, but this does mean a shift might require building a whole new material to ensure the quality of online teaching and learning. Reviewing the previous literature regarding the available professional development programmes increases the need to integrate online teaching competence as a main objective into teacher education and professional development programmes to follow up with the skills of the $21^{\text {st }}$ century students. The framework includes three main domains of teachers' knowledge: Content (CK), which is related to the subject matter and answers the question "what will be taught?" such as concepts, theories and terms; Pedagogy (PK), which refers to teaching strategies required for addressing the students' learning needs; and Technology (TK), which refers to the variety of technologies and instructional materials used, such as learning management systems.
\end{abstract}

Keywords: TPACK; online instructors; online learning; higher education; professional development 


\section{Introduction}

With the rapid growth of technology integration into higher education and the widespread of online learning, teaching expertise now includes new effective strategies and competencies for online instructors (Benson \& Ward, 2013). Higher education institutions aim to enhance digital skills and technology integration into learning environments (Ashe \& Bibi, 2011). However, some studies (Agustini et al., 2019; Cheng, 2017; Jaipal-Jamani et al., 2018) have shown that there is still some faculty resistance in higher education, even with the vast integration of technology. Many instructors usually avoid participation in online activities due to their preference for staying in their comfort zone of traditional teaching. Other barriers include time spent to learn and use the technology, digital competence and digital self-efficacy (Ertmer \& Ottenbreit-Leftwich, 2010; Jaipal-Jamani et al., 2018).

Some recommendations have been suggested by Lye (2013) and Wang et al. (2019) to solve this issue by providing professional development programmes for tutors and online instructors with a focus on pedagogical training to enhance their ability to develop their teaching practice, and designing online courses. Professional development programmes for tutors and instructors are most effective when using Information Communication Technology (ICT) (Qasem \& Viswanathappa, 2016).

Online and distance learning have been started in higher education, yet, many of the instructors are not trained on effective online teaching practice. Although faculties in higher education have started teaching online courses for a while, some studies noticed that the online courses in different disciplines were more generic and less focused on the subject matter content (Anderson et al., 2013). The instructors' knowledge of how to teach an online course is informed by their content knowledge and pedagogical approaches. Furthermore, it is influenced by how to balance technology with both content and pedagogy which is known as The Technological Pedagogical and Content Knowledge (TPACK) framework (Anderson et al., 2013; Soomro et al., 2018).

Jang and Chang (2016) stated that, although many studies have investigated the in-service and pre-service TPACK level, few studies have discussed this topic for university instructors. Online teachers and instructors need to have an awareness of the content, and also are required to gain the knowledge of how technology and online environments affect the pedagogy and the content of what they are teaching (Archambault \& Crippen, 2009). Therefore, it was important to explore how the TPACK model is integrated into professional development programmes for online instructors to be prepared for the rapid growth of online and distance learning in higher education.

\section{Purpose}

This paper aims to review the literature to find how higher education institutions support online instructors with professional development programmes, and how these programmes are shaped by the TPACK framework. Since the TPACK framework is mostly used in tutors' education programs, this paper explored the use of TPACK for online teaching provided in teacher education programmes as 
part of professional development delivered in higher education settings to develop online teaching and learning. Furthermore, the paper aims to summarise effective online teaching practices based on the TPACK framework presented in the literature.

\section{Rationale}

The need for online education is in demand nowadays. Thus, the development of an outstanding educational platform is essential. The importance of this step is to overcome the obstacles that might hamper the education continuity, like these days of COVID-19 crisis. Furthermore, this could be an opportunity to establish a well-designed online source for education, train educators to use this platform and allow students to undertake distance learning. The significance of this study is demonstrated by summarising literature focusing on TPACK framework for online teaching. Moreover, this review study provides a fundamental source to breakthrough in the field of online teaching in higher education. On the other hand, the literature review provided here benefits also decision-makers at institutions to make good use of previous experiences.

\section{Method}

The search was conducted in four scientific databases (i.e. Education Resources Information Center (ERIC), The learning and Technology Library (Learn Tech Lib), ScienceDirect, and Google Scholar) based on terms and titles such as: "TPACK", "TPACK in higher education", "TPACK for K-12 teachers", "TPACK for professional Development", "TPACK for pre-service teachers" "TPACK and online learning", and "TPACK for online instructors".

The search was limited to peer-reviewed articles published in the $21^{\text {st }}$ century during 2000-2020 related to the topic of the paper. The inclusion and exclusion criteria were defined as follows in Table 1:

Table 1: Inclusion and Exclusion Criteria

\begin{tabular}{|c|l|l|}
\hline Criterion & \multicolumn{1}{|c|}{ Inclusion } & \multicolumn{1}{|c|}{ Exclusion } \\
\hline Time period & $2000-2020$ & $\begin{array}{l}\text { Studies outside the } \\
\text { range of these dates }\end{array}$ \\
\hline Language & English & Non -English \\
\hline Type of article & $\begin{array}{l}\text { Articles published in peer } \\
\text { reviewed journals }\end{array}$ & $\begin{array}{l}\text { Articles that were not } \\
\text { peer reviewed or other } \\
\text { types of publications }\end{array}$ \\
\hline Study focus & $\begin{array}{l}\text { TPACK in either K-12 or higher } \\
\text { education online learning, and } \\
\text { TPACK in professional } \\
\text { development for online learning. }\end{array}$ & $\begin{array}{l}\text { All other subjects } \\
\text { teachers, pre-service teachers. }\end{array}$ \\
\hline $\begin{array}{l}\text { Population and } \\
\text { sample }\end{array}$ & $\begin{array}{l}\text { Higher education instructors, K-12 } \\
\text { teachers }\end{array}$ & All other population \\
\hline
\end{tabular}


The search included around 65 Articles, but only 52 were related to the purpose of this review. Keywords and the number of articles searched for each one were as follows in Table 2:

Table 2: Keywords and Number of Articles

\begin{tabular}{|l|l|}
\hline \multicolumn{1}{|c|}{ Keyword } & \multicolumn{1}{c|}{ Number of Articles } \\
\hline TPACK in K-12 & 12 \\
\hline $\begin{array}{l}\text { TPACK in higher education } \\
\text { (including pre-service programmes) }\end{array}$ & 9 \\
\hline TPACK for online teachers and instructors & 13 \\
\hline $\begin{array}{l}\text { TPACK in professional development } \\
\text { (Online and in-campus) }\end{array}$ & 22 \\
\hline
\end{tabular}

\section{Literature Review}

The Technological Pedagogical and Content Knowledge (TPACK) Framework Teaching is a complicated process especially with technology due to the challenges that such technology presents to tutors (Koehler \& Mishra, 2009). In order to comprehend the TPACK framework, it is vital to know its root. Shulman (1986) first introduced the concept of Pedagogical Content Knowledge (PCK) to help teachers improve their teaching practices, and what they should learn and do (Archambault \& Crippen, 2009). He described the relationship between a particular subject matter and the pedagogical practice to teach this subject to the students (Archambault \& Barnett, 2010).

Mishra and Koehler (2006) developed this framework by adding technology as a new component due to technology integration in education. They presented TPACK, the acronym for Technological Pedagogical and Content Knowledge, which is a framework to help teachers in exploring effective teaching practices in a digital context (Kivunja, 2013). TPACK can be defined as the "knowledge that helps teachers to understand how to teach a particular topic using a particular type of technology" (Bibi \& Khan, 2017, 71).

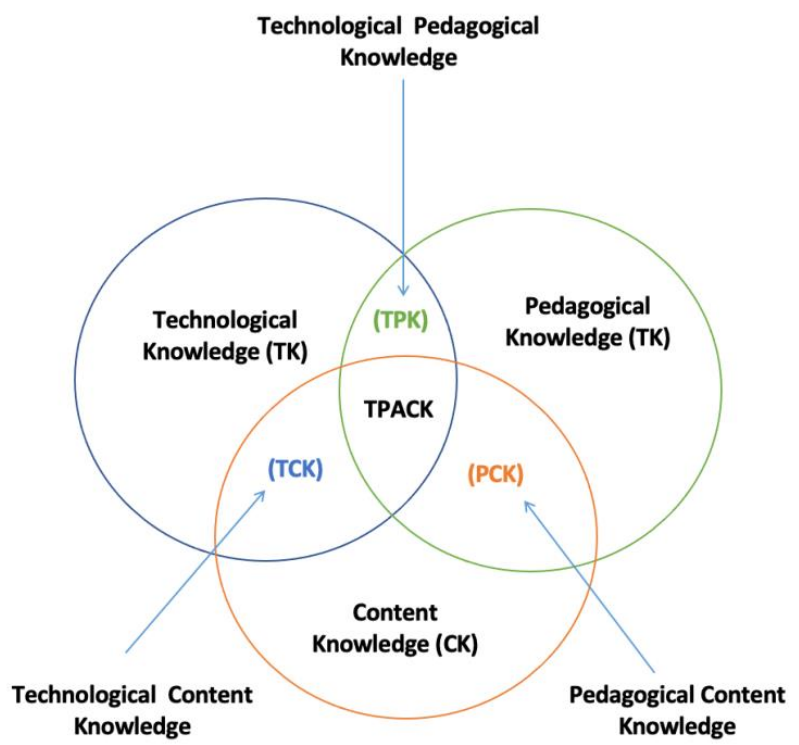

Figure 1: The relationships among the TPACK model 
The framework includes three main domains of teachers' knowledge. The first domain is Content (CK), which is related to the subject matter and answers the question "what will be taught?" such as concepts, theories and terms. The second domain is Pedagogy (PK), which refers to teaching strategies required for addressing the students' learning needs. Lastly, the third domain IS Technology (TK), which refers to the variety of technologies and instructional materials used, such as learning management systems (Koehler \& Mishra, 2009). The interactions among these domains result in three sub-entities which are (Archambault \& Crippen, 2009; Bibi \& Khan,2017; Rosenberg \& Koehler, 2015; Sahin, 2011):

- $\quad$ Pedagogical Content Knowledge (PCK), which is the relationship between content knowledge (What should be taught), and pedagogical knowledge (strategies of teaching).

- Technological Content Knowledge (TCK) is about understating the impact of technology on content knowledge of a specific discipline where teachers can envision how to integrate technology into their teaching.

- $\quad$ Technological Pedagogical Knowledge (TPK) is about the methods and strategies of teaching and learning using technology. It requires an understanding of how using an appropriate instructional design of technology can change teaching and learning.

Some studies found that these domains are significantly related to each other. Other studies also showed a positive relationship between TCK, TPK, and TPACK while others found strong connections between TCK, TPK, TK, and TPACK (Alzahrani \& Cheon, 2015). This emphasised the importance of developing the teachers' TPACK knowledge because of this impact on improving students' learning.

\section{Online Teaching Practice}

Online learning has been developed in higher education, which provides a flexible environment for learners. Online learning expanded in higher education because of its flexibility and ability to distribute information everywhere and also to expand teaching and learning resources (Kuo, 2015). One of the major factors to successfully integrate online learning in higher education is related to the availability of technology and support where the technological part consists of hardware, software and infrastructure. On the other hand, the support resources include online faculty support, for instance (Alsofyani et al., 2013). Many universities offer online professional development workshops for instructors, but being able to attend an online course does not ensure the attendees' ability to incorporate technology in their teaching (Tømte et al., 2015). However, online courses and workshops can serve as venues for developing digital competencies.

Previous studies have explored the impact of several factors, such as teaching experience and age, on the instructors' TPACK level. They found that age does not affect the TPACK significantly; age may play a role in instructors' technology adaptation though because older instructors would not prefer to go out of their teaching comfort zone, especially with the rapid digital transformation (Cheng, 2018). On the other hand, the teaching experience might help the online instructors to gain TPACK skills, but also does not ensure the instructors' abilities to integrate technology in teaching and learning (Jang \& Tsai, 2013). 
Wang et al. (2019) addressed the importance of online teaching competencies, which refer to "knowledge, skills, abilities, and attitudes required to implement online teaching effectively" (p.4). They also addressed the "Competencies for Online Teaching Success (COTS)", which includes six aspects: "attitude/ philosophy, building a learning community, class administration, faculty workload management, teaching and learning, and technology used abilities" (Wang et al., 2019, p.4).

Tondeur et al. (2020) found that TPACK is correlated with six strategies for effective teaching (p.1):

(1) Teacher educators as a role model by using technology in their teaching.

(2) Discussing the role of technology in teaching and learning.

(3) The role of designing in learning how to use technology in education.

(4) Collaboration.

(5) Scaffolding.

(6) Providing continuous feedback.

Effective online teaching improves by effective course design principals, structures and practice (Barham \& Northcote, 2013). De Gagne and Walters (2009) summarised the best practice of online teaching in providing a solid learnercentred environment and visibility. They state that these two factors will increase both teachers' and students' interaction and commitment to the online course.

\section{Planning and instructional design}

Liu (2013) addressed that online teaching has some challenges, such as designing and presenting the course materials to ensure students' learning and communication. Preparing and designing an online course is time-consuming and involves more work than the traditional one (Valtonen et al., 2017). Thus, for an effective integration of technology in education, teachers' planning must embrace curriculum objectives and materials, students' needs to learn, available technologies, and the classroom context (Harris \& Hofer, 2011). Most of the technology professional development is 'technocentric' focusing on the technology features rather than how it can be used to support students' learning (Harris \& Hofer, 2011).

To achieve the goal of using technology in education, teachers need to play the role of instructional designers, and the school environment should support that role with appropriate technologies (Şimşek \& Sarsar, 2019). Many teacher education programmes have refocused their educational technology towards learning by design where pre-service teachers can generate the TPACK for determining subject content by synthesising the six domains of the framework: Pedagogy (PK), Technology (TK), Content (CK), Pedagogical Content Knowledge (PCK), Technological Content Knowledge (TCK), and Technological Pedagogical Knowledge (TPK) (Chai \& Koh, 2017).

The instructional design can be defined as "the study of designing, developing, and assessing learning and teaching environments" (Czerkawski \& Schmidt, 2018, p.1) and it is an important factor to produce a well-designed and good quality course. Hellström et al. (2018) collected data from teacher educators in two higher 
education institutions in Sweden using a survey to observe their perspectives of their digital competence to support students' online learning. They found that all of the teacher educators use digital tools in teaching, but they still rate their ICT competence as low and expressed their need for more training in integrating technology into teaching practice considering the instructional design aspects.

Tømte et al. (2015) used a mixed-method study on two online teacher education programmes in two universities in Sweden and Norway. Through several tools, they collected data for the study to link online teacher practice with students' teachers' practice. The study revealed that most online teachers were more tooloriented and teacher-centred when designing online courses while few of them integrated technology into class in a learner-centred approach. Both online teachers and teacher students appreciate the value that technology brings to pedagogy when they start using TPACK. Some studies (Voogt et al., 2016) demonstrated that modelling and designing support students' teachers in their TPACK development.

The integration of technology in education needs careful planning; hence, teacher education programmes play an important role in preparing future teachers to deliver the content of various subjects using technology (Zainal, 2016). They need to recognise what type of technology to use and when to use it, especially given that not all technology tools are applicable in teaching and learning settings (Koehler et al., 2011). This skill can be acquired by understanding TPACK, which might assist instructors to shift to an online learning context (Ward \& Benson, 2010).

\section{TPACK in Online Teacher Education Programs}

Teacher training is essential to develop their teaching practice (Zhang \& Cai, 2019). TPACK was covered in pre-service teachers' literature because adding technology into the educational environment does not guarantee effective learning unless it is combined with the pedagogical component of how to use this technology with a particular subject matter (Baturay et al., 2017). A study (Jang \& Chen, 2010) showed that pre-service teachers who had good digital skills with training on how to use those skills in their teaching designed better technologybased lessons than those who had good digital skills without training on its use in education.

Mouza et al. (2017) emphasised the 21st century students' skills needed in the digital era, such as learning computational thinking skills. Such a development in many K-12 curriculum across the world highlights the need to offer professional training for pre- and in-service teachers to teach the 'digital natives' (Prenskey, 2001). Using a survey and analysing course materials of a course based on the TPACK framework for a teacher education programme, Mouza et al. (2017) found that this framework had a positive influence on understanding pre-service teachers of computational thinking. Yet, results indicate that pre-service teachers still have some challenges in their comfort level to integrate such a concept in their teaching and discipline content.

Learning how to apply technology is not enough to know how to integrate it into 
teaching and learning. Teacher education programmes usually provide a special technology course for teachers that increases their ICT skills but not how to integrate technology tools in education and combined it with the subject matter (Zainal, 2016). TPACK is a flexible framework that can be compatible with various subjects (Alzahrani \& Cheon, 2015).

Two of the main challenging subjects in schools are science and mathematics. Preservice science teachers should be prepared to integrate and design the curriculum with technology (Jang \& Chen, 2010). Jang and Chen (2010) did a study on science pre-service teachers in which they designed a course consisted of four stages based on TPACK. The first stage was the comprehension of TPACK, the second one was the students observing two experienced science teachers who showed their technology integration with science content as a model for the preservice teachers. The third stage was the students' turn to practice by making plans for innovative use of technology in teaching where they teach individually for 30 minutes. The students' teaching was video recorded to reflect on their performance at the final stage. The results showed that pre-service teachers were able to connect the science knowledge with technology because TPACK helped to combine the three main bodies of technology, pedagogy and content.

There have been some inquiries in the K-12 teacher education literature on the impact of TPACK on the learning process in online environments (Ward \& Benson, 2010). Although preparing pre-service teachers to use technology in teaching is important, in-service teachers are also required to adapt to using technology in teaching in the $21^{\text {st }}$ century. But in-service teachers' professional development opportunities are limited, so online education provides a chance for them to learn and develop their TPACK knowledge while they are still actively teaching (Niess et al., 2010). Niess et al. (2010) explored an online course for inservice teachers on how to use spreadsheets for teaching mathematics and science in K-8 settings. This course was a part of an online master's degree programme focused on using technology with science and mathematics. The researchers followed a case study method in which they analysed the e-portfolios of 12 teachers who participated in the course, interviews' answers, and self-efficacy survey results. They divided the teachers' TPACK into three levels: 1) accepting, teachers are more concerned about the access of technology in their teaching; 2) adapting, teachers use technology in a teacher-directed activity; and 3) exploring, teachers are using technology in student-directed activities. The results found that all 12 teachers appreciated using spreadsheets in their math and science classrooms, but only four of them showed a higher TPACK level and those are the ones who used instructional design to prepare for their teaching; such results emphasise the importance of planning and designing. The researchers suggest that, as teachers continue to explore different technologies, different students, and different content, they need to continue their TPACK development.

Papanikolaou et al. (2017) presented a framework used in a pre-service teacher training programme that adopts a view of teachers designing innovative content as well as interacting with instructors, peers and technology. They designed the course where the study was applied to be around asynchronous collaborative activities based on two educational approaches, TPACK and Community of 
Inquiry (COI). The findings showed strong correlations between TPACK and COI elements, especially regarding cognitive presence.

Teacher educators in teacher education programmes play an important role in modelling technology incorporation by using technology in their teaching (Martin, 2015). Thus, the training provided for faculty in higher education is important to ensure that they represent the right modelling for their students to integrate technology into their teaching practice.

\section{TPACK in Higher Education}

Although the K-12 literature had investigated the TPACK implications on teaching and learning in online environments, the TPACK model was not considered widely in higher education (Ward \& Benson, 2010). One of the domains required to be updated to ensure an effective integration of educational technology and online learning in higher education is faculty knowledge (Alsofyani et al., 2012). This update can be performed by providing faculty training on how to use technology, but with pedagogical knowledge.

Jang and Chang (2016) investigated the instructors' self-perceptions as well as the students' perceptions of the instructors' TPACK. They developed an instrument for assessing university physics instructors' perceptions of their TPACK, and they also assess the differences of the instructors' TPACK according to gender, academic degree and teaching experiences. The findings showed that there were significant results in TPACK related to teaching experience but no statistical significance related to either gender or academic degree. On the other hand, Reyes et al. (2017) used a TPACK-based survey to explore perceptions of pedagogical practices that incorporate ICT at one of the Australian universities. The results found that there is a misconception between how to use ICT and how to teach about ICT. Also, they reported that there are still some gaps between TPACK and ICT application in teaching and practice, so they recommend involving this part in teacher education and teacher educator's professional development programmes.

Soomro et al. (2018) also observed TPACK awareness and adaptation among faculty members of two departments (IT and Education) at one of the universities in Pakistan. The researchers embraced a mixed-methods approach using a survey and interviews. Results found that both faculties are taking steps into TPACK adaptation and integration of ICT (Information and Communication Technologies) into their teaching through personal efforts as well as collaborative work with their peers.

Special education is also covered in the literature. Kuo (2015) conducted an action research to investigate the impact of adding an Integration of Research for Inclusive Settings (IRIS) modules to an online course for a special education teachers' programme. The results revealed that the TPACK framework enabled the instructors to reflect on their teaching to improve their practice. For example, when instructors notice that students do not adequately comprehend a concept or they have a low progress on a certain activity, the instructor can adjust that activity to assist the students in acquiring that knowledge. Also, students can 
revisit the online modules to review the content.

Utami et al. (2019) developed an Android-based application to enhance teaching skills based on TPACK analysis. Their investigation aims to support a microteaching course for novel faculty in the college of engineering to enhance their teaching competence. They identified some teaching challenges for novel faculty such as classroom management, the lack of variety in students' activities, the lack of feedback, and the skill of teaching small groups or individuals. The smartphone application is designed to be interactive and offers an opportunity for prospective teachers to learn and assess their performance. The application includes 1) learning multimedia (images, videos, audio, mind maps, and text) which represent the (TK) part; 2) tutorials and assessment for understanding concepts (PK); 3) concepts and examples of lesson plans (CK); 4) tutorials and assessments about teaching skills (PCK); 5) using the application with features materials and chatbot as well as notifications about teaching progress (TCK); and 6) multiple-choice tests that exercise and assesses teaching skills repeatedly (TPK). Using various media forms, such as videos that give the prospective teachers examples of teaching practice skills, and the mind maps that help them to develop the understanding of the concepts, supports the faculty to comprehend teaching skills.

\section{TPACK in Professional Development for Online Instructors}

Many higher education instructors who never taught an online course tend to have a negative opinion about online instruction because of the lack of professional development that supports online courses in their institutions (Herman, 2012). Some studies found that the teaching practice among disciplines was more generic than expected (Anderson \& Barham, 2013). Professional development for instructors in higher education is usually led by an instructional technologist who has limited knowledge about the particular content or subject that the instructors are teaching (Dysart \& Weckerle, 2015). Because of that, the (TCK) area is usually covered by the instructor, which may affect the technological pedagogical knowledge and may not be covered appropriately.

The available professional development for online instructors differs in their types among higher education institutions. Herman (2012) identifies five main types of professional development provided for online instructors as follows:

(1) Self-teaching:

Faculty members who prefer self-teaching methods, either because of budget issues or because of their learning styles, can find self-taught online materials such as e-books, videos, recorded online seminars and journal articles. Online instructors can find some online self-assessment methods for their online courses as well.

\section{(2) Peer mentoring:}

Mentor-based faculty professional development is an approach provided in some institutions to support their online instructors. Mentoring can be in a formal programme or informal relationship where mentors are chosen for their experience in teaching online courses. Some professional development programmes use a team mentoring approach. 


\section{(3) Collaborative course design:}

This type of professional development is a part of an ongoing mentoring. The mentor serves as a tutor to design an online course and as an evaluator of the online instructor's work at the same time.

\section{(4) Workshops:}

There are two types of workshops, 'one shot' and long workshops. The 'one shot' takes place over a few hours or a full day but this type of professional development cannot assist the instructors to connect pedagogy and technology, so the TPACK framework cannot be covered in such workshops. On the other hand, there are longer time workshops that take place from two days to months.

\section{(5) Online training:}

Online training allows the online instructor to try online environments before teaching their online courses. It can be provided either synchronous (teacher and students need to be available online at the same time) or asynchronous (students can check the materials at their own pace).

The impact of good professional development programmes for online instructors was examined by Storandt et al. (2012). The study continued for three terms where the online instructors also taught their courses and finished a background survey and interviews. The professional development programme followed four phases to ensure high quality training: modelling the skills required for online instructors, preparation by providing online training, providing ongoing support during the course, and feedback to ensure that the instructors attained the needed skills. The results found that the professional development guidelines provided in the training received positive feedback from the instructors.

A TPACK-based technology workshop for online instructors was provided by Jaipal-Jamani et al. (2018). The online instructors took the role of leaders by presenting a workshop to colleagues. The workshop consisted of four phases:

(1) Modelling a technology-enhanced learning activity.

(2) Engaging in a dialogue about applying this planned activity in different subject matter contexts.

(3) Learning technical skills required for applying the activity.

(4) Applying the required technical skills.

The results found that the instructors gained different skills and knowledge about TPACK and it is affected by their experience of teaching with technology in the workshop.

Another professional experience was a course provided to the nurse educators to teach online. Kraglund-Gauthier and Moseley (2019) conducted a participatory action research on 15 nurse educators who teach online courses aiming to "build capacity in pedagogy and teaching- learning process in the online courses" (p.6). They provided a professional development TPACK-based course that took place in three phases: planning, action, and reflection. In the planning phase, the participants reviewed the literature and selected strategies and evaluation approaches that they might incorporate. Second, they used the strategies as well 
as having individual sessions with an instructional designer to assist them through the process of 'action'. During the last phase, 'reflection', they revised outcomes of the strategies and make recommendations. The findings revealed five themes emerged to teach online with technology: community, instructors, classrooms, interpersonal relationships, and supports. Regarding the community theme, they summarised the importance of building a community of learners and practice while the instructors theme emphasised their needs and skills to teach online. In the classroom theme, they summarised the optimal size to be 20-30 students and that they need to be active and engaged as well as building their knowledge upon scaffolding activities through discussion, for instance. The interpersonal relationships included respect among learners and instructors in addition to the cooperation concept. The last theme, 'supports', stressed the importance of having a technology and pedagogy coach to ensure course and teaching quality.

Wang et al. (2019) devolved an instrument based on the activity theory to study the Chinese beginning online instructors' competencies to teach online. The results showed that age and gender do not have a significant influence on online teaching competencies; yet, the educational level and online teaching and learning experience do have a significant influence on online teaching competencies. On the other hand, designing and organising an online course and students' evaluation were the main challenges for the online instructors. Wang et al. (2019) recommend to gather and analyse online instructors' course data rather than the self-report survey to understand more online teaching competencies.

\section{Conclusions}

TPACK can improve the creativity, collaboration and responsibility of learning. TPACK is a flexible framework, but it is context-based. Therefore, the TPACK framework cannot provide a clear explanation for the success of online teachers in online teaching. This ability includes learning the teaching design principles of online environments, and how to organise and promote student communication and interaction through these online environments. The survey results found that, although teacher educators have a new understanding of computational thinking and ICT skills, they still face some challenges in integrating concepts into the comfort zone of teaching and subjects. This can be solved by suggesting the addition of a technical leadership role to the TPACK professional development programme, with participants taking the lead in designing and presenting related seminars. Professional development plans that prepare online teachers to design, promote and evaluate their online courses are essential. Teacher educators also play an important role in these programmes, simulating the integration of technology in their teaching, and presenting more online teaching challenges when designing classroom activities. The results emphasise that the key to effective online teaching practice is to cultivate teachers' reflective ability to build on their existing knowledge and better understand their abilities and status in the profession. Online teaching is a challenge, and it does not mean that physical classroom teaching and activities will be transferred to online platforms, but this transformation may require the construction of entirely new materials to ensure the quality of online teaching and learning. A review of previous literature on available professional development programmes has increased the need to 
incorporate online teaching capabilities as the main goal into teacher education and professional development programmes to follow up on the skills of students in the 21st century.

\section{References}

Agustini, K., Santyasa, I. W., \& Ratminingsih, N. M. (2019). Analysis of Competence on "TPACK": 21st Century Teacher Professional Development. In Journal of Physics: Conference Series, 1387(1). IOP Publishing. https://doi.org/10.1088/1742$6596 / 1387 / 1 / 012035$

Alsofyani, M. M., Aris, B. B., Eynon, R., \& Majid, N. A. (2012). A Preliminary Evaluation of Short Blended Online Training Workshop for TPACK Development Using Technology Acceptance Model. Turkish Online Journal of Educational TechnologyTOJET, 11(3), 20-32. https://eric.ed.gov/?id=EJ989196

Alsofyani, M. M., bin Aris, B., \& Eynon, R. (2013). A Preliminary Evaluation of a Short Online Training Workshop for TPACK Development. International Journal of Teaching and Learning in Higher Education, 25(1), 118-128. https:/ / eric.ed.gov/?id=EJ1016428

Alzahrani, A., \& Cheon, J. (2015). The Effects of Instructors' Technological Pedagogical and Content Knowledge (TPACK) on Online Courses. In Society for Information Technology \& Teacher Education International Conference, 3044-3049. Association for the Advancement of Computing in Education (AACE). https://www.learntechlib.org/p/150429/

Anderson, A., Barham, N., \& Northcote, M. (2013). Using the TPACK Framework to Unite Disciplines in Online Learning. Australasian Journal of Educational Technology, 29(4). https://doi.org/10.14742/ajet.24

Archambault, L., \& Crippen, K. (2009). Examining TPACK Among K-12 Online Distance Educators in the United States. Contemporary issues in technology and teacher education, 9(1), 71-88. https://www.learntechlib.org/p/29332/

Archambault, L. M., \& Barnett, J. H. (2010). Revisiting Technological Pedagogical Content Knowledge: Exploring the TPACK Framework. Computers \& Education, 55(4), 1656-1662. https:// doi.org/10.1016/j.compedu.2010.07.009

Ashe, D., \& Bibi, S. (2011). Unpacking TPACK and Students' Approaches to Learning: Applying Knowledge in Pieces to Higher Education Teaching and Learning. In Proceedings Ascilite Hobart (pp. 128-132). Retrieved from https://www.researchgate.net/profile/David-

Ashe/publication/254560771_Unpacking_TPACK_and_students\%27_approach es_to_learning_Applying_knowledge_in_pieces_to_higher_education_teaching and_learning/links/5b72bf9b45851546c9028d8b/Unpacking-TPACK-andstudents-approaches-to-learning-Applying-knowledge-in-pieces-to-highereducation-teaching-and-learning.pdf

Baturay, M. H., Gökçearslan, S., \& Sahin, S. (2017). Associations among Teachers' Attitudes towards Computer-Assisted Education and TPACK Competencies. Informatics in Education, 16(1), 1-23. https://doi.org/10.15388/infedu.2017.01

Benson, S. N. K., \& Ward, C. L. (2013). Teaching With Technology: Using TPACK to Understand Teaching Expertise in Online Higher Education. Journal of Educational Computing Research, 48(2), 153-172. https://doi.org/10.2190/ec.48.2.c

Bibi, S., \& Khan, S. H. (2017). TPACK in Action: A Study of a Teacher Educator's Thoughts When Planning to Use ICT. Australasian Journal of Educational Technology, 33(4). https://doi.org/10.14742/ajet.3071 
Chai, C. S., \& Koh, J. H. L. (2017). Changing Teachers' TPACK and Design Beliefs Through the Scaffolded TPACK Lesson Design Model (STLDM). Learning: research and Practice, 3(2), 114-129. https:// doi.org/10.1080/23735082.2017.1360506

Chang, Y., Jang, S. J., \& Chen, Y. H. (2015). Assessing University Students' Perceptions of their Physics Instructors' TPACK Development in Two Contexts. British Journal of Educational Technology, 46(6), 1236-1249. https://doi.org/10.1111/bjet.12192

Cheng, H. J. (2018). A TL-TPACK Model on CSL Pre-service Teachers' Competencies of Online Instruction. In Teacher Training and Professional Development: Concepts, Methodologies, Tools, and Applications, 280-308. IGI Global. https:// doi.org/10.4018/978-1-5225-0483-2.ch011

Czerkawski, B. C., \& Schmidt, N. (2018). ITET: Instructional Design Practices in Teacher Education. Issues and Trends in Learning Technologies, 6(2). https://doi.org/10.2458/azu_itet_v6i2_czerkawski

De Gagne, J. C., \& Walters, K. (2009). Online Teaching Experience: A Qualitative Metasynthesis (QMS). MERLOT Journal of Online Learning and Teaching, 5(4). https://jolt.merlot.org/vol5no4/abstracts.htm

Dysart, S., \& Weckerle, C. (2015). Professional Development in Higher Education: A Model for Meaningful Technology Integration. Journal of Information Technology Education: Innovations in Practice, 14(1), 255-265. https:/ / doi.org/10.28945/2326

Ertmer, P. A., \& Ottenbreit-Leftwich, A. T. (2010). Teacher Technology Change: How Knowledge, Confidence, Beliefs, and Culture Intersect. Journal of Research on Technology in Education, 42(3), 255-284. https://doi.org/10.1080/15391523.2010.10782551

Harris, J. B., \& Hofer, M. J. (2011). Technological Pedagogical Content Knowledge (TPACK) in Action: A Descriptive Study of Secondary Teachers' CurriculumBased, Technology-related Instructional Planning. Journal of Research on Technology in Education, 43(3), 211-229. https://doi.org/10.1080/15391523.2011.10782570

Hellström, L., Stigmar, M., \& Amhag, L. (2018). Teacher Educators' Use and Needs of Digital Competence to Support Students' Online Learning. IOSTE 2018. https://doi.org/10.1080/21532974.2019.1646169

Herman, J. H. (2012). Faculty Development Programs: The Frequency and Variety of Professional Development Programs Available to Online Instructors. Journal of Asynchronous Learning Networks, 16(5), 87-106. https://doi.org/10.24059/olj.v16i5.282

Jaipal-Jamani, K., Figg, C., Collier, D., Gallagher, T., Winters, K. L., \& Ciampa, K. (2018). Developing TPACK of University Faculty Through Technology Leadership Roles. Italian Journal of Educational Technology, 26(1), 39-55. https://www.learntechlib.org/p/184086/

Jang, S. J., \& Chen, K. C. (2010). From PCK to TPACK: Developing a Transformative Model for Pre-service Science Teachers. Journal of Science Education and Technology, 19(6), 553-564. https://doi.org/10.1007/s10956-010-9222-y

Jang, S. J., \& Chang, Y. (2016). Exploring the Technical Pedagogical and Content Knowledge (TPACK) of Taiwanese University Physics Instructors. Australasian Journal of Educational Technology, 32(1). https://doi.org/10.14742/ajet.2289

Jang, S. J., \& Tsai, M. F. (2013). Exploring the TPACK of Taiwanese Secondary School Science Teachers Using a New Contextualized TPACK Model. Australasian Journal of Educational Technology, 29(4). https://doi.org/10.14742/ajet.282

Kivunja, C. (2013). Embedding Digital Pedagogy in Pre-service Higher Education to Better Prepare Teachers for the Digital Generation. International Journal of Higher Education, 2(4), 131-142. https://doi.org/10.5430/ijhe.v2n4p131 
Koehler, M., \& Mishra, P. (2009). What is Technological Pedagogical Content Knowledge (TPACK)? Contemporary Issues in Technology and Teacher Education, 9(1), 60-70. https://doi.org/10.1504/ijlt.2011.042646

Koehler, M. J., Mishra, P., Bouck, E. C., DeSchryver, M., Kereluik, K., Shin, T. S., \& Wolf, L. G. (2011). Deep-play: Developing TPACK for 21st Century Teachers. International Journal of Learning Technology,6(2), 146-163. https://doi.org/10.1504/ijlt.2011.042646

Kraglund-Gauthier, W., \& Moseley, J. (2019). Building Teaching-Learning Capacities of Online Nurse Educators: Using TPACK to Frame Pedagogical Processes and Identify Required Supports| Renforcer les capacités d'enseignement et d'apprentissage des éducateurs en ligne en soins infirmiers: utiliser le modèle TPACK pour encadrer les processus pédagogiques et repérer les soutiens requis. Canadian Journal of Learning and Technology/La revue canadienne de l'apprentissage et de la technologie, 45(1). https://doi.org/10.21432/cjlt27595

Kuo, N. C. (2015). Action Research for Improving the Effectiveness of Technology Integration in Preservice Teacher Education. ie: inquiry in education, 6(1), 3. Retrieved from https://files.eric.ed.gov/fulltext/EJ1171686.pdf

Liu, S. H. (2013). Exploring the Instructional Strategies of Elementary School Teachers When Developing Technological, Pedagogical, and Content Knowledge via a Collaborative Professional Development Program. International Education Studies, 6(11), 58-68. https:// doi.org/10.5539/ies.v6n11p58

Martin, B. (2015). Successful Implementation of TPACK in Teacher Preparation Programs. International Journal on Integrating Technology in Education, 4(1), 17-26. https://doi.org/10.5121/ijite.2015.4102

Mishra, P., \& Koehler, M. J. (2006). Technological Pedagogical Content Knowledge: A Framework for Teacher Knowledge. Teachers College Record, 108(6), 1017-1054. https://www.learntechlib.org/p/99246/?nl=1

Mouza, C., Yang, H., Pan, Y. C., Ozden, S. Y., \& Pollock, L. (2017). Resetting Educational Technology Coursework for Pre-service Teachers: A Computational Thinking Approach to the Development of Technological Pedagogical Content Knowledge (TPACK). Australasian Journal of Educational Technology, 33(3). https://doi.org/10.14742/ajet.3521

Niess, M. L., van Zee, E. H., \& Gillow-Wiles, H. (2010). Knowledge Growth in Teaching Mathematics/Science with Spreadsheets: Moving PCK to TPACK through Online Professional Development. Journal of Digital Learning in Teacher Education, 27(2), 42-52. https:// doi.org/10.1080/21532974.2010.10784657

Papanikolaou, K., Makri, K., \& Roussos, P. (2017). Learning Design as a Vehicle for Developing TPACK in Blended Teacher Training on Technology Enhanced Learning. International Journal of Educational Technology in Higher Education, 14(1), 34. https:// doi.org/10.1186/s41239-017-0072-z

Prensky, M. (2001). Digital Natives, Digital Immigrants. On the Horizon, 9(6), 1-6. https://doi.org/10.1108/10748120110424843

Qasem, A. A. A., \& Viswanathappa, G. (2016). Blended Learning Approach to Develop the Teachers' TPACK. Contemporary Educational Technology, 7(3), 264-276. https://doi.org/10.30935/cedtech/6176

Reyes Jr, V. C., Reading, C., Doyle, H., \& Gregory, S. (2017). Integrating ICT into Teacher Education Programs from a TPACK Perspective: Exploring Perceptions of University Lecturers. Computers \& Education, 115, 1-19. https://doi.org/10.1016/j.compedu.2017.07.009 
Sahin, I. (2011). Development of Survey of Technological Pedagogical and Content Knowledge (TPACK). Turkish Online Journal of Educational TechnologyTOJET, 10(1), 97-105. https://eric.ed.gov/?id=EJ926558

Simsek, Ö., \& Sarsar, F. (2019). Investigation of the Self-Efficacy of the Teachers in Technological Pedagogical Content Knowledge and Their Use of Information and Communication Technologies. World Journal of Education,9(1), 196-208. https://eric.ed.gov/?id=EJ1208813

Soomro, S., Soomro, A. B., Ali, N. I., Bhatti, T., Basir, N., \& Gill, N. P. (2018). TPACK Adaptation among Faculty Members of Education and ICT Departments in University of Sindh, Pakistan. International Journal of Advanced Computer Science and Applications, 9(5). https://doi.org/10.5430/wje.v9n1p196

Storandt, B. C., Dossin, L. C., \& Lacher, A. P. (2012). Toward an Understanding of What Works in Professional Development for Online Instructors: The Case of PBS Teacherline. Journal of Asynchronous Learning Networks, 16(2), 121-162. https://doi.org/10.24059/olj.v16i2.216

Tømte, C., Enochsson, A. B., Buskqvist, U., \& Kårstein, A. (2015). Educating Online Student Teachers to Master Professional Digital Competence: The TPACKframework Goes Online. Computers \& Education, 84, 26-35. https://doi.org/10.1016/j.compedu.2015.01.005

Tondeur, J., Scherer, R., Siddiq, F., \& Baran, E. (2020). Enhancing Pre-service Teachers' Technological Pedagogical Content Knowledge (TPACK): a Mixed-method Study. Educational Technology Research and Development, 68(1), 319-343. https://doi.org/10.1007/s11423-019-09692-1

Utami, P., Pahlevi, F. R., Santoso, D., Fajaryati, N., Destiana, B., \& Ismail, M. E. (2019). Android-based Applications on Teaching Skills Based on TPACK Analysis. In IOP Conference Series: Materials Science and Engineering, 535(1). IOP Publishing. https://doi.org/10.1088/1757-899x/535/1/012009

Valtonen, T., Sointu, E., Kukkonen, J., Kontkanen, S., Lambert, M. C., \& Mäkitalo-Siegl, K. (2017). TPACK Updated to Measure Pre-service Teachers' Twenty-First Century Skills. Australasian Journal of Educational Technology, 33(3). https://doi.org/10.14742/ajet.3518

Voogt, J., Fisser, P., Tondeur, J., \& van Braak, J. (2016). Using Theoretical Perspectives in Developing an Understanding of TPACK. In Handbook of technological pedagogical content knowledge (TPACK) for educators (pp. 43-62). Routledge.

Wang, Y., Wang, Y., Stein, D., Liu, Q., \& Chen, W. (2019). Examining Chinese Beginning Online Instructors' Competencies in Teaching Online Based on the Activity Theory. Journal of Computers in Education, 6(3), 363-384. https://doi.org/10.1007/s40692-019-00140-w

Ward, C. L., \& Benson, S. K. (2010). Developing New Schemas for Online Teaching and Learning: TPACK. MERLOT Journal of Online Learning and Teaching, 6(2), 482-490. https://jolt.merlot.org/vol6no2/ward_0610.pdf

Zainal, N. F. (2016). TPACK Development in Teacher Education Programs: Malaysian Context. International Journal of Academic Research in Business and Social Sciences 2016, 6(12), 237-244. https://doi.org/10.6007/ijarbss/v6-i12/2490

Zhang, S., Liu, Q., \& Cai, Z. (2019). Exploring Primary School Teachers' Technological Pedagogical Content Knowledge (TPACK) in Online Collaborative Discourse: An Epistemic Network Analysis. British Journal of Educational Technology, 50(6), 34373455. https://doi.org/10.1111/bjet.12751 